\title{
ADOPTION OF GREEN PRACTICES IN MANUFACTURING SMES: SOME LESSONS FROM KOCHI, KERALA, INDIA
}

\author{
* Kumudinei Dissanayake \\ Department of Management \& Organization Studies, \\ University of Colombo, Sri Lanka \\ S. P. Premaratne \\ Department of Economics, University of Colombo, Sri Lanka \\ Sudheera Ranwala \\ Department of Plant Science, University of Colombo, Sri Lanka \\ Nayani Melegoda \\ Faculty of Graduate Studies, University of Colombo, Sri Lanka
}

\begin{abstract}
Adopting green practices in the manufacturing sector has become a requirement for achieving Sustainable Development Goals (SDGs). Manufacturing Small and Medium scale Enterprises (SMEs) play a major role in the industrial sector in Sri Lanka. However their contribution towards reaching a green economy is not well documented. Efforts in adopting green practices, failures or success stories, and the problems and issues associated with green manufacturing in SMEs are yet to be examined in depth in the Sri Lankan context. As a means of acquiring a priori knowledge on the reality, this study aims to explore the green practices, challenges and strategies, and the required institutional support for implementing and sustaining such practices in manufacturing SME sin a geographical location similar to Sri Lanka i.e., Kochi, India. Thus, the objective of this study is to identify important lessons from experiences undergone by manufacturing SMEs in the adoption of green practices in their businesses. This is an exploratory study conducted by collecting qualitative data from interviewing the stakeholders of selected manufacturing SMEs visited for this purpose. The study takes a deductive approach, deriving its analytical framework from the review of literature. A set of green practices, challenges to be anticipated, and the institutional and policy support required in implementing and sustaining green practices in
\end{abstract}


manufacturing SMEs are identified as lessons to be learned. The study concludes that the successful implementation and sustaining of green practices in manufacturing SMEs need their own will and drive of owners and employees, supported by government intervention for promoting and ensuring sustainable green practices. The findings of the study propose a conceptualization for validating in a future empirical study.

Keywords: Adopting green practices; Implementing and sustaining green practices; India; Kochi; Lessons; Manufacturing SMEs; Sri Lanka

\section{Introduction}

Green manufacturing is emerging as a mainstream concept in manufacturing at present. This is due to its emphasis on the concepts of 'sustainability' and 'safe environment' which covers the interests of a wide range of stakeholders including international organizations, global society and even future generations. As such, 'greening' of the manufacturing entities may lead to creating a green economy which could beget benefits to the entire society. Thus, irrespective of their stage of development, countries are adopting green practices in manufacturing towards the achievement of the SDGs. India and Sri Lanka are among them (Dayaratne \& Gunawardana, 2014; Sajan, Shalij, Ramesh, \& Biju, 2017; Thanki \& Thakkar, 2014).

SMEs contribute a substantial portion of the gross domestic product (GDP) in both developed and developing countries. Therefore, they have to contribute to the green economy. Previous studies have particularly highlighted a variety of reasons as to why SMEs should adopt green practices or green manufacturing. These include numerous pull factors as well as push factors (Stopper, Kossik \& Gastermann, 2016) and positive stands and negative stands. SMEs, when compared to large organizations, are more prone to legislation requirements and stakeholders' pressures (Esty \& Winston, 2006), thus pulling them towards the adoption of green practices. At the same time, SMEs are significant contributors to the overall emissions and releases of toxic materials which are negatively affecting the environment (Parker, Redmond \& Simpson 2009; Yacob et al., 2013), thus resultantly they are pushed towards adoption of green practices. 
Some scholars stand on a positive view when justifying the SMEs' need of 'going green', arguing that "consumer demand for environment friendly goods and services as well as the escalating costs of waste disposal have triggered environment-related business opportunities for the SMEs" (Yacob, Wong, \& Khor, 2019, p. 6). Yacob et al. (2019) maintain that SMEs who successfully respond to market forces and are innovative enough to reduce waste generation and environmental costs will gain a competitive advantage. Thus, the nature and character of SMEs (e.g., flexibility and innovation) have placed them in a better position to implement green practices (Esty \& Winston, 2006). However, SMEs' negligence of green efforts is also highlighted by researchers on the grounds that they perceive that the responsibility of protecting the environment is completely at the hands of the local authority and planners, rather thanat their own (Vernon et al., 2003).

In addition to these, the existing knowledge indicates that the aspirations of SMEs towards 'being green' and their real actions towards the same are not aligned due to factors such as lack of education and training (Williams \& Schaefer, 2013). Further, the complicated nature of balancing both operational or financial performance and sustainability of SMEs (Sajan et al., 2017) and the lack of adequate knowledge and tools required to implement green practices in their operations (Burke \& Gaughran, 2007) have been constraints.

The history of SMEs in Sri Lanka shows that they have dominated Sri Lankan industrialization during the past decades. Economic Censes in 2013/14 indicated that SMEs play a significant role in Sri Lankan industrialization accounting for 98.5 percent of industrial establishments. SME establishments doubled during 2004 to 2014 time period, while the number of large establishments decreased from 1402 in 2004 to 720 in 2014 ${ }^{1}$. Employment in SMEs in 2014 was 633,933 which is 50 percent higher compared to 2004. SMEs value addition to the economy in 2004 and 2014 were 31.6 percent and 31.1 percent respectively (DCSSL, 2015; 2017).

About 8 percent of non-agricultural economic activities come under SMEs in Sri Lanka. SMEs generate about 30.5 percent of total non-agricultural employment.

${ }^{1}$ However, this trend can be observed everywhere in the world since industrial organizations were changed 'hierarchy to 'market' and then market to further 'network' 
Among the 30.5 percent of total SME employment (917107), about 50 percent is generated in the industrial sector. The other two sectors, trade and service, generate 20.8 percent and 29.3 percent respectively. Meanwhile, 30.4 percent of non-agricultural SMEs are in the industrial sector. The highest numbers of SMEs are in service sector, representing 44.2 percent of total SMEs. A large proportion of these establishments and employments is found to be concentrated in three groups of industries: a) food, beverages and tobacco, b) textile, apparel and leather products, and c) non-metallic mineral products(DCSSL, 2015; 2017).

From the above it is evident that in the case of Sri Lanka, SMEs contribute significantly to the industrial sector and the economy at large.. Hence, they, especially the manufacturing SMEs need to comply with green practices. On one hand manufacturing SMEs need to counter the voices raised by internal stakeholders for waste reduction, elimination of inefficiencies, and employee health and safety measures, and on the other hand they are compelled to respond to the institutional pressures flowing from the government compliances, consumer reactions, and general public concerns (Wadhwa, 2014). In addition to this, Manufacturing Matters (2011) reports that "greening of manufacturing is essential to any effort to decouple environmental pressure from economic growth" ( $p$. 6).However, the level of green adoption of SMEs or manufacturing SMEs in Sri Lanka has not been well documented. SMEs operating in Sri Lanka also experience pressures from numerous stakeholder groups for adopting green practices in their manufacturing systems and processes. However, the greening efforts of the SMEs in Sri Lanka, their failures or success stories, and the problems and issues associated with green manufacturing are yet to be examined in depth at individual and national level.

It is apparent that a comprehensive base knowledge on the green initiatives, green practices, challenges and strategies in implementing and sustaining them in SMEs, gained from the perspective of diverse stakeholders, is required for understanding the ground realities of the same in Sri Lanka. Thus, the present research aims to study this phenomenon in a research context which is similar to the locale, and still rich with manufacturing SMEs those well initiated and have adopted green practices during the past. Therefore, Kochi commercial city in the Ernakulam district of Kerala, India was selected as the research site of the present study. Accordingly, the research questions raised to answer in the present study are 
as follows: (a) how the green practices have been adopted by the manufacturing SMEs in Kochi, (b) what are the challenges encountered in adopting green practices by manufacturing SMEs in Kochi, and how they have strategized to overcome them, and (c) what are the lessons learnt through Kochi experiences. Thus, the objectives of this study are three-fold: (a) to explore the green practices adopted by manufacturing SMEs in Kochi, (b) to examine the challenges encountered and strategies used/ designed to overcome such challenges at individual and institutional level in Kochi, and (c) to draw lessons for adopting green practices in manufacturing SMEs in Sri Lanka(or similar other contexts). This study is significant in providing implications for the manufacturing SMEs in the Sri Lankan context, especially in line with the possible green practices to be adopted. Manufacturing SMEs, especially those located in developing economies, are vulnerable to numerous challenges in introducing and implementing green practices. The findings of an exploratory study of this nature broaden the horizon of knowledge on possible alternative strategies that could be designed at the level of individual enterprises. In addition to it, how a manufacturing city like Kochi has set the grounds for facilitating its industrialists would bring important implications for institutional actors and policy makers at the local context.

The paper is structured as follows: Introduction, a review of literature covering the basic existing knowledge on green manufacturing and green practices, followed by an elaboration of the methods adopted for facilitating the replication of the study. Presenting the detailed findings with a discussion in line with green practices, challenges and strategies and institutional support systems available/ or recommended, the lessons for Sri Lanka will be drawn with policy implications and directions for further studies.

\section{Review of Literature}

\subsection{Green SMEs}

Green SMEs have been defined as "SMEs those which embrace green processes and/or produce green products/services using green production inputs" (Ramessur, 2018, p.35). According to Ramessur (2018), green SMEs, different to traditional SMEs, focus more on social and environmental requirements, combined with economic desires. Some examples of the application of greening in 
SMEs include production by using solar energy, recycling waste, and smart metering. These SMEs can be benefitted with higher prices for green products, possibility of obtaining raw materials for a low cost, opportunity for developing competitive advantage, implementation of innovative solutions and creation of new market niches(Ramessur, 2018).

\subsection{Green manufacturing}

Green manufacturing (sustainable or environmental-friendly manufacturing) refers to transforming materials into products without giving rise to emission of greenhouse gases, use of non-renewable or toxic materials or generation of waste (Allwood, 2009). Thus, the aim of green manufacturing is to optimize the industrial production (Dornfeld, 2012) and to reduce or minimize the negative effects of production processes on the ecosystem (Mafini \& Loury-Okoumba, 2018) by reducing the negative externalities associated with waste and pollution (Manufacturing Matters, 2011).It is an effort of "harmonizing the pursuit of economic benefits" (Baines et al. 2012, p. 61). As elaborated by Baines et at. (2012), green production is achieved through the actions such as producing from greener materials and by greener operations and processes, delivering greener outcomes, and being greener to dispose of at the end of their life" (p. 67).As reported in the Manufacturing Matters (2011), the "successful implementation of green manufacturing requires going beyond small standalone initiatives, and adopting an integrated framework" (p. 7). Thus, recognizing "planning for greening' as an essential part of the business strategy, executing green initiatives across the value chain, and communicating and promoting green initiatives and their benefits to all stakeholders are noted as requirements for such an integrated framework.

Collaborations with all stakeholders of the business are essential for implementing and sustaining green manufacturing even in SMEs. As per Baines et al. (2012), "sustainability includes considering an extended set of stakeholders, including the environment, as well as the global community and future generations" ( $p$. 64).Thus, collaborations with suppliers and customers to be environmentally friendly and training employees and support from employees for green manufacturing are noteworthy in mentioning (Arun \&Noble, 2017). These need to be supported by the internal systems of the organization which may include an eco-design,controls on pollution, continuous checking, standardisations, and adoption of ISO 14001 certification etc.(Arun \&Nobel, 2017). 
There are several important are as need to be considered in green manufacturing, such as environmental impact of product(s), location of manufacturing plants, manufacturing processes, manufacturing systems, material utilization within materials requirements planning, capacity and inventory planning and control, supply chain management, quality control: cost or rework, scrap disposal, total quality management systems and failure prevention and recovery (Sainidis \& Robson, 2017). Moreover, as elaborated by Hartinia and Ciptomulyonob (2015), a green operations system incorporates a number of elements such as product redesign, process redesign, disassembly, substitution, recycling, remanufacturing, consuming internally, prolonged use, returnable packaging, spreading risks, creating markets, waste segregation, and alliances.

\subsection{Green practices in manufacturing}

Dornfled's (2014) research on green and sustainable manufacturing sheds light on some important and initial parameters for greening the manufacturing SMEs which suggests that enterprises need to practice the reduction of weight and increase of the yield of manufacturing goods while increasing the product life span. In a broader sense, Arun and Nobel (2017) introduce green practices to be adopted in line with five parameters, namely, internal environment management, technology integration, logistic management, customer focus, and supplier focus. Past studies have highlighted the green practices adopted in the manufacturing sector in different lines. They have accorded attention under the themes: usage of resources, energy consumption, handling of waste, handling of pollution, recycling, product life cycle management, water reservation, and labour force protection.

Efficient use of resources is a green practice in which 'avoiding the use of resource in the first place' and 'reducing the environmental footprint of a resource' have been emphasized (Dornfled, 2014) in manufacturing entities. Thus, reducing and/ or leveraging the use of resources (Dornfled, 2014) and enhancement of the use of materials consumed (Li \& Huang, 2012) have been noted as green practices of manufacturing entities. In addition to these, practices such as adopting designs with environment-friendly raw materials, parts and components and accommodating more biodegradable and recyclable materials (Mitra \& Datta, 2014; Zhu, Sarkis \& Geng, 2005; Zhu, Sarkis, and Lai, 2012) have been pointed out in the existing literature. 
Energy management (Yacob et al., 2019) and reducing energy consumption (Lin \& Huang, 2012) are noted as green practices. A study of the UK-based manufacturing SMEs reveals that the adoption of automated lighting and electricity generating solar panels and searching for alternative manufacturing energy sources (e.g. changeover from electricity to gas) can be used as green practices in SMEs (Sainidis \& Robson, 2017). Adopting 'green technology' (Rao $\&$ Holt, 2005) has been identified as a method of energy saving in manufacturing. Using cleaner energy (Yacob et al., 2019) has also been emphasized for achieving further savings in the use of energy. Use of green technology is further recommended for saving water and reducing waste.

Proper recycling of waste (Sezen \& Cankaya, 2013) and reducing the cost of recycling (Dornfled, 2014) are also noted as attempts towards greening the manufacturing. According to Sainidis and Robson (2017), designing recycling policies for manufacturing waste by-products or supply packaging is another important green practice in manufacturing. Waste management (Yacob et al., 2019) and efficient disposal of hazardous products (Sezen \& Cankaya, 2013) in general, and the activities for reducing waste generation and minimizing the byproducts of wastes in particular, help in greening attempts (Lin \& Huang, 2012). Further, product designs facilitating easy disassembly of products for reuse and recycling is also recommended (Zhu, Sarkis \& Geng, 2005; Zhu, Sarkis \& Lai, 2012).

As noted by Yacob et al. (2019), adoption of pollution prevention approaches (aiming at both compliance and competitive advantage) and using pollution control measures are some of the initiatives taken by manufacturing SMEs for assuring environmental sustainability. Sainidis and Robson (2017) show some avenues for handling environmental pollution by maintaining low emissions and chemical outputs and through installation of systems for cleaning and extraction in manufacturing entities.

Product life cycle management is also an important aspect in greening efforts where certain practices such as reducing the product weight and increasing the product life span have been noted (Dornfled, 2014).Product life cycle management has been well linked to the lean concept in manufacturing enterprises in the perspective of 'next generation of lean thinking' (Grieves, 2006). Barreto et 
al. (2007) elaborated that green initiatives and strategies are needed in all five stages of the product life cycle (plan, design, build, support, and dispose). They have examined how product life cycle management drives green manufacturing to improve environmental performance.

Green practices have not been limited to products, resources and waste handling, but encapsulate labour and working conditions too. Thus, Lin and Huang (2012) view that the actions for reducing occupational health and safety hazards and for improving general workplace safety are significant in greening efforts. Protection of the labour force from environmental hazards and providing a conducive working environment are some of the strategies used in green manufacturing (Sezen \& Cankaya, 2013).In addition to these, the general areas for ensuring employee health and safety concerns such as training employees for adopting green practices, protecting the labour force, reducing occupational health and safety hazards, improving general workplace safety, maintaining a conducive environment, and environmental training for employees (Arun \&Nobel, 2017; Berry\& Rondinelli, 1998; Daily \& Huang, 2001; Dubey et al., 2014; Lin \& Huang, 2012; Sezen \& Cankaya, 2013; Wee \& Quazi, 2005; Zutshi \&Sohal, 2004) have been highlighted in the past research.

Quintás, Martínez-Senra, and Sartal (2018)examined nine environmental practices for understanding the adoption of 'green business model' in SMEs. Those practices included (a) energy and environmental audits, (b) life cycle analysis, (c) ecological design, (d) eco-labeling, (e) use of best available techniques, (f) valorization of sub-products and waste, (g) use of waste to generate power, (h) cogeneration and trigeneration, and (i) use of renewable energies.

\subsection{Challenges encountered by SMEs in greening}

The implementation and sustaining of greening efforts made by SMEs have been impeded by several practical issues visible in their internal and external environments. The 'cost factor' has been significant due to financial and investment constraints encountered by SMEs (Dornfeld, 2012), especially in developing economies. Ramessur (2018) notes that SMEs' lack of access to finance due to reluctance from financial institutions to finance risky "green" projects and the scarcity or absence of expert staff to assess such projects is a challenge for greening SMEs. Consequent to this cost factor, physical 
infrastructural blockages (Manufacturing Matters, 2011) have also affected greening in SMEs. The 1st Green Manufacturing Summit held in India in 2011 revealed that outdated labour laws and cascading taxes restrict SMEs in adopting green practices (Manufacturing Matters, 2011). In the same line of view, existing literature finds that 'technology barrier' has played a role in limiting greening efforts of SMEs (Dornfled, 2012). Lack of new technology, materials and processes, complexity to design, reuse/recycle products, lack of technical expertise have been highlighted as the barriers in the implementation of green supply chain management in the Indian context (Govindan, Kaliyan, Kannan, \& Haq, 2014).

Further to the above, lack of knowledge and awareness on green practices has been another significant challenge for the manufacturing SMEs. Lack of environmental knowledge (Ghazilla et al. 2015) and the managers' scarce environmental training and short-term orientation, and the staff's scarce environmental awareness and training(del Brío \& Junquera, 2003) have challenged the adaption of green practices in SMEs. Lack of environmental consciousness by the firms (Min \& Galle, 2001) also aggravates this challenge. As noted by Govindan et al. (2014), lack of professionals exposed to green systems, lack of environmental knowledge, perception of "out-of-responsibility" zone, disbelief about environmental benefits, lack of awareness about reverse logistics have created barriers on successful implementation of green practices. In addition to these, lack of training courses/ consultancy/ institutions to train, monitor and mentor progress specific to each industry are also noted by Govindan et al. (2014). Ramessur (2018) adds to this in his revelation that unawareness of available opportunities for green venturing(due to information asymmetry), deficiency of the needed skills and expertise to capitalise on available green opportunities, lack of reliable partners to share risks and lack of proper regulatory framework and conducive environment to support SMEs in their green initiatives have altogether challenged green initiatives in SMEs.

Dornfled (2012)reiterates that lack of suitable measurements, control and management tools in SMEs have restricted their adaption and sustaining of green efforts. Further, lack of environmental standards and auditing programmes (Min $\&$ Galle, 2001) and the scarce influence of manufacturing process flexibility (del Brío \& Junquera, 2003) have been highlighted as barriers for greening the 
manufacturing enterprises. The SMEs' lower ability to obtain highly radical innovations and their lack of relational ability with external stakeholders (del Brío \& Junquera, 2003) also noted as challenging the greening efforts. According to Ghazilla et al. (2015), several issues related to the internal organisation, business environment, social influence, financial and supplier matters have hindered the adaption of green practices in SMEs in the Malaysian context. Govindan et al. (2014) report that lack of government support to adopt environment friendly policies also contributes to such challenges in the Indian context.

2.5 What drives entrepreneurs to overcome challenges in adopting green practices?

Hines et al. (1987) theorized that knowledge, skills, personality and situational factors are affecting the responsible environmental behaviour of people. They found that knowledge of (environmental) issues, knowledge of action strategies, locus of control, attitudes, verbal commitment, and an individual's sense of responsibility are associated with his/her responsible environmental behaviour. As Ajzen (1991; 2012) theorizes, (behavioural) intention is the immediate antecedent of human behaviour, and it reflects on function of three determinants; (a) attitudes towards the behaviour, (b) subjective norms with respect to the behaviour, and (c) perceived control over the behaviour. Steg and Vlek (2009) identified five important factors determining the environmental behaviour of people such as (a) perceived costs and benefits, (b) moral and normative concerns, (c) affect, (d) contextual factors and (e) habits. Sawitria, Hadiyantob, and Hadi (2015), in line with the underpinnings of the social cognitive theory, suggested that self-efficacy, outcome expectations, goals, contextual support, and action are important determinants of environmental behaviour. In addition to these, the entrepreneurs with environmental concerns have been identified as green entrepreneurs or ecopreneurs (Santhini, 2017). Green Business Bureau (2020) notes that ecopreneurs use innovative approaches to solve old problems and thus capitalize on environmental problems. This has proven the credibility of an ecopreneur. Demonstrating commitment to sustainability has been the most important action of an ecopreneur. According to Kirkwood and Walton (2010), the basic motivators for ecopreneurs are the green values, earnings, passion, being his/her own boss, and seeing an opportunity in the market. Ecopreneurs can be of four types: (1) innovative opportunists (influenced by hard structural factors such 
as regulation), (2) visionary champions (whose business is founded on the basis of sustainability), (3) ethical mavericks (influenced by soft structural drivers such as past experience), and (4) ad hoc enviropreneurs (accidental green entrepreneurs) (Gibbs, 2009). Accordingly, it is evident that successful encounter of challenges in'greening' efforts of enterprises are mainly influenced by the soft (personal) facets of the SME owners and the hard facets like external factors.

As indicated above, even SMEs do not step into innovative actions unless there are foreseen outcomes to reap. The outcomes of the environmental behaviour in enterprises usually come in the form of incentives, rewards and even satisfaction gained through the involvement in green adoption. Thus, incentives are reached in terms of long-term cost savings, brand enhancements, better regulatory traction, and greater ability to attract talent and higher investor interest (Manufacturing Matters, 2011). Zhu and Sarkis (2004) and Zhu et al. (2008) proposed the relationship between adoption of green supply chain practices and the performance of the enterprises (e.g., economic performance, operational performance and environmental performance).

\subsection{Regulatory and other institutional policy instruments helpful for greening}

Two key policy priorities for greening manufacturing have been recommended by the United Nations Environment Programme (UNEP).They are: (a) promoting closed-cycle manufacturing and related life cycle approaches with supportive recovery and recycling infrastructure, and (b) regulatory reform to enable factor efficiency improvements in energy use (e.g. through the introduction of cogeneration and combined heat and power technologies) (Manufacturing Matters, 2011, p. 9) in manufacturing settings. In addition to these, UNEP highlights several instruments that government institutions may use to support the greening of industry and manufacturing. They include: (a) regulatory and control mechanisms, (b) economic or market-based instruments, (c) fiscal instruments and incentives, and (d) voluntary actions, information and capacity building. The regulatory and control actions that could be taken by government institutions are noted as building cleaner technology standards and performance standards, creating markets for green products, and encouraging industries to use natural resources more efficiently. The Manufacturing Matters further elaborates the economic and market based instruments suggested by UNEP (2011) in terms of introducing charges and fees for non-compliance, liability payments, tradable 
permit systems targeting air pollution, water quality and land management, instruments regulating the price, and charges targeting emissions and products (at the level of manufacturing, use or disposal), as well as by-products such as packaging and batteries. The fiscal instruments and incentives suggested by UNEP include: fiscal policy (comprising public expenditure, subsidies and taxation), tax exemptions to be made for specific products or industry sectors, and tax revenues to be earmarked for a specific purpose. Finally, voluntary actions and capacity building can be performed through the supply of instruments and provision of information instruments (such as product information, labelling and reporting) (p.9).

Examining the role of SMEs' in green business models, Quintás et al. (2018) revealed that SMEs need help when transforming towards a low-carbon economy. Accordingly, they highlighted the need of administrative actions, legislative actions (on environmental protection measures), training actions (on available environmental techniques), promotion of research (on how to adopt such techniques to SMEs) and the development of specific practices for SMEs in adopting environment friendly practices.

\subsection{Summary of the literature review}

There are numerous studies, conducted all over the world, reflecting on important aspects of green practices and green manufacturing in SMEs. Some of the highlights are as follows. Links between lean and green manufacturing have been examined through empirical as well as review studies (Hartinia, \& Ciptomulyonob, 2015; Miller et al., 2010; Sawhney et al., 2007; Wadhwa, 2014). The implementation phase of green manufacturing has gained research attention in developing and developed contexts (Ajin, Raju, \& Prasanth, 2015; Arun \& Noble, 2017; Matt \& Rauch, 2013). Green initiatives, lean manufacturing and environmental sustainability have also been researched extensively (Sajan et al., 2017; Stopper et al., 2016; Tiwari \& Tiwari, 2016; Yacob et al., 2019). Moreover, environmental behaviour (Steg \& Vlek, 2009; Sawitria, Hadiyantob, \& Hadi, 2015),green supply chain management activities and performance (Dubey, Bag \& Ali, 2014; Dües et al., 2013; Mafini. \& Loury-Okoumba, 2018) also can be noted as a well-attended research agenda of contemporary times.

Most of the attempts made in past studies provide us a general understanding of green practices that "should be adopted" in "enterprises" (if not they particularly 
focused on SMEs) in prescriptive sense. In addition to the summed up knowledge in the form of books (Dornfeld, 2012), a considerable volume of such writings appear in the form of overviews (Conde et al., 2015; Sanyal \& Eisinger, 2016), literature reviews and theories (Bhateja et al., 2011; del Brío, \& Junquera, 2003; Setyaningsih \& Indarti, 2018), models or categorizations (Defi, 2011; Govindan et al., 2015; Jaiswal \& Kumar, 2018; Quintás, Martínez-Senra, \& Sartal, 2018). In addition to action research on capacity building (Kaur, Gupta \& Syal, 2016), case studies (Defi, 2011; Lee, 2009) and questionnaire surveys (Mitra \& Datta, 2014; Zhu \& Sarkis, 2004; Lina, \& Sheub, 2012) have been conducted in the arena of present research. However, there have been few exploratory studies, looking in depth into ground realities of green adoption in SMEs.

There are many past studies conducted on diverse facets of green adoption and related areas. Among them, ample studies report on green supply chain management (Caniëls, Cleophas \& Semeijn, 2016; Dhillon, n.d.; Dhillon, Bentley \& Bukoye, 2016; Hsu, 2013; Kumar, Kumar \& Ram, 2015; Mitra \& Datta, 2014; Tachizawa, Gimenez, \& Sierra, 2015; Zhu, Sarkis and Lai, 2013) and green manufacturing (Allwood, 2009; Arun \& Patrick, 2017; Dornfeld, 2012; Mafini. \& Loury-Okoumba, 2018; Sainidis \& Robson, 2017). In contrast researchpublications on the areas of green finance (Conde et al., 2015; Sanyal \& Eisinger, 2016), green management (Lee, 2009), green advice (The Economics Times, 2015), and green innovation (Zeng, et al., 2014) also exist but in comparatively smaller numbers. Some studies have looked into problems associated with green efforts (Manufacturing Matters, 2011), factors impeding green implementation (Dornfeld, 2012; Gopal et al., 2018; Jaiswal \& Kumar, 2018; Liu, Low, \& He, 2012). However, the present study focuses on three important aspects in relation to the adoption of green practices in manufacturing SMEs i.e. green manufacturing practices, challenges (at individual and institutional level), strategies and lessons (from good practices).

Adoption of green practices has been investigated in different regions or geographical locations across the globe, such as, India (Dhillon, Bentley \& Bukoye, 2016; Gopal et al., 2018; Jaiswal \& Kumar, 2018; Kaur, Gupta \& Syal, 2016; Kumar, Kumar \& Ram, 2015), China (Liu, Low, \& He, 2012;Zeng, Lin, Ma, Qi, \& Tam, 2014), Malaysia (Ghazilla et al., 205; Kasim \& Ismail, 2012; Yacob, Wong, \& Khor, 2019), Spain (Tachizawa, Gimenez, \& Sierra, 2015), Czech 
(Alena \& Libor, 2012), USA (Ashton, Russell \& Futch, 2017; Min, \& Galle, 2001), UK (Sainidis \& Robson, 2017), Brazil, Indonesia, and South Africa (Sommer, 2017), Philippines (Conde et al., 2015), Korea (Lee, 2019), South Africa (Mafini. \& Loury-Okoumba, 2018). The past studies available on green adoption in the Sri Lankan context have been limited. Some available literature can be found in the areas of sustainable construction practices (Athapaththu \& Karunasena, 2018), overview of green financing trends (Conde et al., 2015), and green reporting in rubber industry (Dayaratne, Wickremathillake \& Gunawardana, n.d.).

Another observation made in the literature review is that the implementation phase of green practices in SMEs has been devoted more attention in the existing literature, sustaining the adopted green practices of such enterprises has been accorded less attention. Present study focuses on both adoption and sustaining of green practices in SMEs. Moreover, survey has been the method of enquiry, combined with quantitative analysis in most of the past research in manufacturing SMEs, rather than deploying on-site exploratory visits for gaining deeper understanding of the ground realities in the green operations of SMEs (e.g., Mafini. \& Loury-Okoumba, 2018; Sajan et al., 2017; Yacob et al., 2019). However, a qualitative approach into several case firms is considerably imperative and promising in an 'applied research' project of an exploratory nature.

\section{Methods}

\subsection{Research site}

With the aim of studying the suggested phenomenon in a context which is similar to the locale, and still rich with manufacturing SMEs those have initiated and adopted green practices, we identified the Kochi commercial city in the Ernakulam district of Kerala, India.The reason for selecting this location was backed by the matter that Kerala is well known for adoption of green practices in manufacturing sector (as well as in the service sector) and the gathering of SMEs in the Kochi city in the Ernakulam district. Kochi city is globally known for locating the world's first international airport operated solely by natural energy (solar power). Currently, the city is taking numerous actions towards green growth. The priority sectors for green growth of the city are: land-use and density, ecosystem and bio diversity, water and sanitation, and housing and buildings (Abbu et al., 2015). 
State of Kerala is known for the industries in the micro, medium and small enterprise (MSME) sector. The industries coming under the MSME sector in the Kerala area include handicrafts, handloom, Khadi, food processing, garment, textile, and industries related to coir, wood, bamboo, plastic, rubber, leather, clay, and electronic/electric components. The institutions facilitating the MSME sector in the area include the Directorate of Industries and Commerce of Government of Kerala, the Directorates of Handloom \& Textiles, the Directorate of Coir and Khadi, and Village Industries Board (Economic Review, 2016). The prominence of manufacturing MSMEs in Kerala is shown in the following two figures by illustrating the number of firms registered and the production, investment and employment in the MSME sector in the past few years.

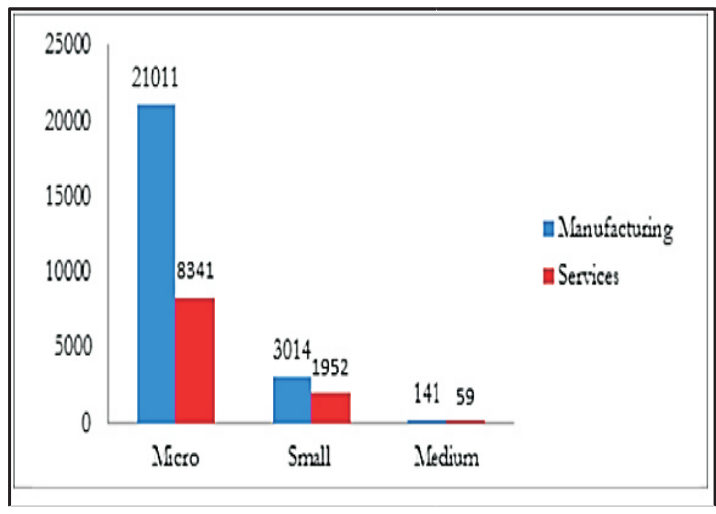

Figure 1:Number of micro, small and medium units registeredunder manufacturing andservices sector in Kerala, 2016-17

Source: Economic Review (2016)

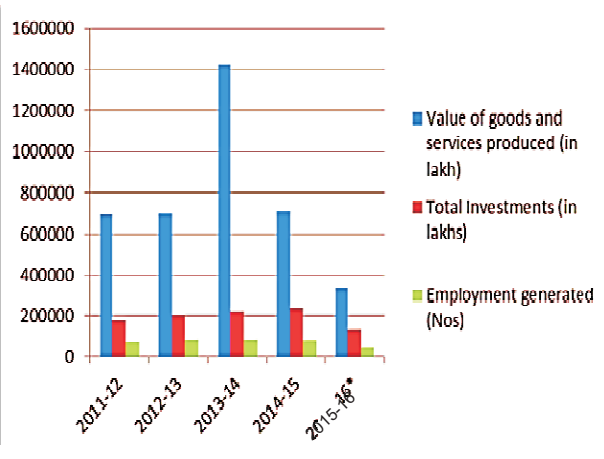

Figure 2Production, investment and employment in MSME sector in Keralafrom 2011-12 to 2015-16 Source: Economic Review (2016)

\subsection{Sources of data and data collection}

The study was conducted by a team of researchers who visited Kochi for data collection. The team had a visit to the Cochin University of Science and Technology where they had an informal discussion with a team of academic experts in the area of this research with prior arrangements. Five experts representing both the industrial sector and the academia were involved in the intellectual discussion held on this subject at the outset. The green initiatives adopted in the area were introduced at the discussion. The case organizations in the two industries were selected in line with the information received in the 
discussion. This discussion and the arrangements made by the local (Kochi) experts eased the data collection at the site.

Present study adopted a qualitative enquiry to answer the research questions. The data requirements of the study were identified as (a) the hands-on experiences of manufacturing SMEs in adopting green practices, (b) the ground realities of challenges encountered by manufacturing SMEs in greening their systems and processes, and (c) the institutional facilitation for supporting the greening efforts. Thus, data gathering took place by means of (a) discussions with the SME owners and relevant stakeholders of the business, (b) discussions with the academic experts in the subject area, and (c) observations at the research site. Two case organisations representing the clothing industry and essential oil industry from the manufacturing SMEs in Kochi were selected for the study based on the nature of their environment-friendly manufacturing. One of the case organizations isoperated asan eco-clothing store in which they promote and sell clothing, accessories and home décor. They have started the operations in 2016 on the concept of promoting and selling organic cotton and handloom products. Later, expanding to the product categories such as bags, home décor, bamboo products, earrings, braceletsand some other eco-friendly items, they became known as a multi-branded store in the Kerala area. They have stepped into distinctive designs with the collaborations of popular and budding artists and designers. They had a base of material suppliers who complied with the eco-friendly production requirements, and the organization was in continuous collaborations with them. The other case organization was operated in the production of essential oils (which were extracted from plants) with the use of organic raw materials. Essential oil production uses a number of processes including extraction, distilling, expressing or clod-pressing to mention a few, thus allowing the producers to employ a number of green practices throughout the process. The case organization concerned in the study was engaged in B2B business where they sell the final products to the wholesale outlets and a few retailers. They had collaborative farmers who were adhering to organic farming.

The study was exploratory in its nature, and the qualitative data were sought through interviews. The interviews were held with the owners of the selected enterprises with the hope of probing into their hands-on experiences on green practices and the challenges encountered. The data collection was conducted 
during January 21-24, 2019 by the team of researchers. The analytical framework developed before the visit was used as a guide in the interviews. The green practices adopted, challenges, and strategies used were the main focus in the data collection, thus, three members of the research team took charge of probing into each area. Interviews commenced with a friendly introduction of the research team and the purpose of the study. In support of the data gathering, observing the manufacturing site was allowed by the owners. Note-taking during the interviews and analysing data were conducted by the same team. Content analysis was used in deriving the findings.

\subsection{Analytical framework}

The green manufacturing practices, challenges encountered by manufacturing SMEs when adopting such practices, and the institutional support or policy instruments were analysed by using the following framework, as informed by the above review of literature.

\section{Table 1: Analytical framework of the study}

\begin{tabular}{|c|c|c|}
\hline $\begin{array}{l}\text { Green Man ufacturing Practices } \\
\text { (GMPs) }\end{array}$ & Challenges Encountered & $\begin{array}{l}\text { Institutional Support/ } \\
\text { Policy Instruments }\end{array}$ \\
\hline $\begin{array}{l}\text { Usage of res ources } \\
\text { Energy consumption } \\
\text { Handling of wastes } \\
\text { Handling of pollution } \\
\text { Recycling } \\
\text { Product life cycle management } \\
\text { Preservation of resources } \\
\text { Labour force protection from } \\
\text { hazards } \\
\text { Handling health and safety }\end{array}$ & $\begin{array}{l}\text { Capital investment and financing } \\
\text { Technology } \\
\text { Knowledge and awareness } \\
\text { Measures and tools } \\
\text { Internal organizational support } \\
\text { Human resource competencies } \\
\text { Regulations and other controls } \\
\text { Social influence } \\
\text { Attitudinal is sues }\end{array}$ & $\begin{array}{l}\text { Regulatory and control } \\
\text { mechanisms } \\
\text { Economic or market-based } \\
\text { instruments } \\
\text { Fiscal instruments and } \\
\text { incentives } \\
\text { Information provision and } \\
\text { capacity building }\end{array}$ \\
\hline
\end{tabular}

The strategies used for mitigating the challenges were identified in the study through analysing data.

\subsection{Ethical considerations}

The research team was fully sensitive to the ethical considerations relevant to the study. Accordingly, anonymity and privacy of all respondents were regarded highly, and the confidentiality of the individual and enterprise information was maintained. In addition, voluntary participation of respondents, informed consent, and protection from harm and victimisation were also followed in principle. 


\section{Findings and Discussion}

\subsection{Green manufacturing practices}

Our discussions with the SME owners of the case organizations revealed a number of green practices adopted by them in their manufacturing enterprises. The findings can be outlined as follows:

a. Manufacturing with zero waste

Manufacturing SMEs usually encounter the problem of waste disposal, especially when they are located in urban areas with a lack of waste disposal facilities, thus discouraging them from adopting green practices. The conversion of Vetiver root waste into natural ayurvedic bath scrubbers by the essential oil production organisation set an example for effective recycling of bio-degradable waste thus demonstrating zero wastes while claiming a competitive advantage in the $\mathrm{B} 2 \mathrm{~B}$ market.

b. Seasonal manufacturing

It is noted that the case organisations adopt the practice of producing goods out of the natural raw materials available in that particular season thus avoiding operations in the manufacturing plant for all products throughout the year. This practice has enabled efficient handling of the manufacturing plant capacity as well as efficient purchasing of raw materials directly from the farmers (contract farming).

c. Using natural raw materials and re use of the rejects

Further, one of our case organisations evidenced that they could sustain with the use of only ground (well) water for their manufacturing purpose as the resource is of satisfactory good quality. Another organisation engaged in the clothing industry not only demonstrated the 'eco-friendliness' of their enterprise by using only natural raw materials such as organic cotton, Kenaf and Jute fiber, but also designing garments in a fashionable way to accommodate the use of rejected fibre pieces from the weaving process. The same enterprise also extracts dyes from natural plants to colour their exclusive clothes which are sold at a high price as value-added products to the customers. With this, they have been able to avoid the use of chemicals in their manufacturing process. 
d. Minimizing the use of machines while optimizing the human labour In general, the clothing industry has the advantage of producing handmade/woven garments replacing the heavy use of machinery to save fuel energy. This enables clothing manufacturers to obtain the maximum use of human resources if they offer a sufficient level of training and provide facilities for maintaining the well being of the workforce. According to Joseph (2010), India still seeks labour for work despite its prevailing industrialization. Proving this fact, it was noticed that one of the case organisations in the clothing industry has gone green by sticking to the use of labour instead of using machines in cloth manufacturing. For an example, they used hand-embroidering in the production of handloom and Khadi dresses, when it comes to detailed embroidering. The other case organization has provided residential facilities to its staff and laborers in the neighbourhood of the company to a reduced rent thus enabling them successfully engaging in the shift basis of work schedules and be punctual at all times. It was noted that such facilities have ensured the continuous service from them and helped reduce the carbon footprint via providing them the option of walking or cycling to work.

\section{e. Recycling of water}

It was also noticed that many manufacturing enterprises in Kerala consider water as a precious resource and thus demonstrate the commitment to reuse of waste water. In such events the organisations had their own storage tanks of water which was treated once in every six months.

\section{f. Educating employees on green practices}

Case organisations also revealed that the employees are regularly educated on 'green practices' that they should follow at the manufacturing company. Further, the staff is provided with residential facilities so that they may well get into the work with full attention. They have adopted a shift basis, and the staff was well trained for the work.

g. Energy saving mechanisms at small and large scales

Going green was also exhibited by the manufacturing industries through obtaining energy via solar power. Using 'clean energy' (gas) in their manufacturing process 
was focused upon as it would eliminate the release of a heavy volume of carbon dioxide. The use of clean energy was preferred to the traditional sources of energy such as sawdust and coconut shells.

In addition to these, there is a remarkable large scale project of energy saving (use of solar power) in Kerala. That is the Cochin International Airport Limited (CIAL) which is the first fully solar-powered airport in the world, thus setting one of the best examples for energy serving projects at mass scale.

h. Popularizing green initiatives and products

It was noticed that the manufacturing SME owners that we interviewed have taken the initiative of helping local communities (societies and small scale cooperatives) for adopting green practices, manufacturing 'green products' and promoting the use of green products (which are recycled, pure, organic, handcrafted and eco-friendly) by reflecting their demand and their consistent use.

\subsection{Challenges encountered and strategies used/recommended}

Interviews conducted in the study also revealed the main challenges the SME owners face when going green in their manufacturing processes. One SME owner noted that securing natural (supplementary) materials for the uninterrupted production is a challenge as the materials are imported from overseas or from a local area not in close proximity. This can be identified as 'resource dependency' (Pfeffer \& Salancik, 1978) which occurs when depending on natural resources for the green manufacturing. However, the other case organisation had used the strategy of contract farming and seasonal production for enabling smooth and uninterrupted production.

Shifting from the use of non-renewable energy to the use of renewable energy in the manufacturing process had required a huge capital investment for SMEs as initial installation costs (example: establishment of bio gas plants, solar power systems). However, one of the case enterprises has introduced the use of solar power in a gradual process thus, stage by stage, in order to overcome this burden. One industry expert highlighted that the adoption of solar power energy in a service sector organization at mass scale was initiated in order to face the challenge of increased electricity prices in the Kerala state. This indicates that some challenges have brought positive results in greening efforts. 
There are several case studies based in the Kochi city in Kerala in order to identify the issues and propose strategies for managing solid waste, reducing waste footprint and managing sustainable watershed in its residential areas (e.g., Ravi \& Vishnudas, 2016; 2017a; 2017b).Discussions with the academic experts in the subject matter in this local area, supported by their publications based on the case studies revealed a number of challenges encountered in implementing and sustaining green practices by the manufacturing SMEs. A considerable attention was accorded on the difficulty in investing in the initial capital needs for the installation of new technological systems such as bio gas technology (Ravi \& Vishnudas, 2017a). In addition to this, Ravi and Vishnudas (2017a) pointed out the lack of knowledge and awareness of standards, design and construction of the plants for adopting such systems by the manufacturing enterprises. In line with this, an expert shared her view on the matter stating, "There is a need to educate the people at the grass root level, so, SME owners need awareness on waste reduction, re-sue and recycle too". She further added,

Educational and awareness programmes for SME owners need to focus on shortterm practices and then they should be continued gradually in the long-run. For an example, we have to start with simple sign board displays such as eco-labelling on "how to use", and then proceed up to education of 'how to be energy efficient'.

A challenge faced by Indian SMEs when shifting into more clean and efficient production systems has been the obsolete technologies that impede such transitions (Gopichandran, Shah, Patel \& Harinarayana, 2013). Gopichandran et al. (2013) note that the Indian government has designed the strategy called 'Credit Linked Capital Subsidy Scheme' to help upgrade technologies (2013, p. 217) in order to overcome this challenge.

Another challenge in the greening efforts is that people have developed unfavourable attitudes towards the technology on renewable energies due to their experiences in the failure of the plants generating such energies. Thus, Ravi and Vishnudas (2017a) iterate the need of publicising such technologies and making awareness programmes in the urban residential areas of Kochi city. They recommend motivational programmes to be conducted through governmental and non-governmental officials, community leaders and other influential persons and the provision of subsidies for installing renewable energy plants as strategies to 
address this issue. Further to this, the field investigations conducted in the Kochi city area have revealed that people are unaware of the effective handling, application, composting and proper use of certain waste items. Accordingly, training on such applications for the people who are handling them has been recommended in this area (Ravi \& Vishnudas, 2017a).

\subsection{Institutional support and policy instruments}

The government of India has designed policy guidelines to facilitate SME sector. One such policy guideline has been outlined in the Small Industries Development Bank of India (SIDBI) in its Annual Report 2010-2011 (SIDBI, 2011) which refers to the Prime Minister's Task Force for developing policy guidelines to support SMEs (Gopichandran et al. 2013, p. 216).According to Gopichandran et al. (2013), India has used some development assistance from overseas too for improving energy efficiency and facilitating cleaner production in SMEs. Improving efficiency in SMEs has been backed by green loan schemes, green rating projects and programmatic clean development mechanism. Further, there are community services established for supporting green efforts. The Green Environment Services Cooperative Society (a forum for collective environmental actions)is one of the examples of this kind.

\subsection{Lessons to be learnt on green manufacturing practices and institutional support systems}

Based on the findings of the exploratory study conducted in the Kochi city, supported by the expert opinions, and relevant literature, the following can be drawn as the lessons to be learnt on the green manufacturing practices and institutional support systems to be adopted in manufacturing SMEs. 
Table 2: Lessons learned on green practices

\begin{tabular}{|c|c|}
\hline $\begin{array}{c}\text { Proposed Green Manufacturing } \\
\text { Practice (GMP) }\end{array}$ & Operationalization \\
\hline Usage of resources & $\begin{array}{l}\text {-Optimum usage of natural resources and } \\
\text { reduce the use of synthetic material } \\
\text {-Using indigenous raw materials for } \\
\text { production as much as possible, heavy } \\
\text { use when they are abundant in relevant } \\
\text { growing seasons } \\
\text {-Using organic materials as raw materials } \\
\text {-Minimizing the use of chemicals as much } \\
\text { as possible and replace them with } \\
\text { alternative natural materials }\end{array}$ \\
\hline Energy consumption & $\begin{array}{l}\text { - Consuming eco-friendly energy } \\
\text {-Using solar power as the major source } \\
\text { of energy }\end{array}$ \\
\hline Handling of wastes and pollution & $\begin{array}{l}\cdot \text { Recycling of waste and reusing them as } \\
\text { by-products, without releasing them } \\
\text { to environment }\end{array}$ \\
\hline Recycling & $\begin{array}{l}\text { - Recycling of water and reusing it without } \\
\text { releasing waste water to canals/ } \\
\text { residential areas }\end{array}$ \\
\hline Product life cycle management & $\begin{array}{l}\text {-Planning product life cycle in line with } \\
\text { seasonal availability of raw materials }\end{array}$ \\
\hline Preservation of resources & - Reusing the existing buildings \\
\hline $\begin{array}{l}\text { Labour force protection and } \\
\text { handling health and safety }\end{array}$ & $\begin{array}{l}\text {-Optimisation of human resource use } \\
\text { to minimize energy driven machinery } \\
\text {-Educating employees on green } \\
\text { practices by SMEs themselves } \\
\text {-Providing on-the-job training on } \\
\text { green practices } \\
\text { - Making the workforce committed to } \\
\text { green practices }\end{array}$ \\
\hline
\end{tabular}




\begin{tabular}{|l|l|}
\hline Manufacturing techniques & $\begin{array}{l}\text {-Using labour/ converting production } \\
\text { process into labour intensive } \\
\text { processes in order to avoid/ reduce } \\
\text { the use of non-green materials and } \\
\text { facilities }\end{array}$ \\
\hline Other & $\begin{array}{l}\text {-Promoting green products } \\
\text { Helping peer groups to adopt green } \\
\text { practices }\end{array}$ \\
\hline
\end{tabular}

The following can be depicted as the lessons learnt on overcoming the challenges in adopting green practices. These lessons are not limited to SMEs but extended up to general public.

\section{Table 3: Lessons learned on overcoming challenges}

\begin{tabular}{|c|c|}
\hline Challenges & Operationalization (overcoming) \\
\hline $\begin{array}{l}\text { Securing natural materials for the } \\
\text { uninterrupted production }\end{array}$ & $\begin{array}{l}\text { - } \quad \text { Collaborations with the suppliers } \\
\text { - } \quad \text { Contract farming } \\
\text { Planned consumption based on seasonal production of } \\
\text { materials }\end{array}$ \\
\hline $\begin{array}{l}\text { Capital investment for shifting to } \\
\text { renewable energy }\end{array}$ & $\begin{array}{l}\text { Adopting solar power in a gradual (stage-by-stage) } \\
\text { process }\end{array}$ \\
\hline $\begin{array}{l}\text { Fear of shifting to new energy due } \\
\text { experienced failures }\end{array}$ & $\begin{array}{l}\text { Creating awareness on renewable energies and new } \\
\text { technologies } \\
\text { Publicising the new technologies and new renewable } \\
\text { energies }\end{array}$ \\
\hline Handling of wastes and pollution & - $\quad$ Strengthening awareness through education \\
\hline Recycling & - Creating awareness and training for such practices \\
\hline Preservation of resources & - $\quad$ Creating awareness \\
\hline
\end{tabular}

Further, the following can be noted as the lessons (or recommendations) on institutional support systems to be provided for promoting green practices in manufacturing SMEs. 
Table 4: Lessons learned on institutional support systems

\begin{tabular}{|c|c|}
\hline $\begin{array}{l}\text { Institutional Support/ Policy } \\
\text { Instruments }\end{array}$ & Operationalization \\
\hline Regulatory and control mechanisms & $\begin{array}{l}\text { - } \\
\text { - } \\
\text { - } \\
\text { Regulate the use of renewable energy in manufacturing } \\
\text { innovative green practices and processes of } \\
\text { manufacturing SMEs } \\
\text { - Recognise and appreciate successful green initiatives of } \\
\text { manufacturing SMEs }\end{array}$ \\
\hline $\begin{array}{l}\text { Economic or market-based } \\
\text { instruments }\end{array}$ & - Popularize more green products among local customers \\
\hline \multirow[t]{2}{*}{ Fiscal instruments and incentives } & - Provision of tax incentives for using renewable \\
\hline & $\begin{array}{ll}\text { - } & \text { Prergies } \\
\text { - } & \text { Tax benision of incentives for adopting green practice } \\
\text { and green technologies }\end{array}$ \\
\hline $\begin{array}{l}\text { Information provision and capacity } \\
\text { building }\end{array}$ & $\begin{array}{l}\text { - Cultivate opportunities for green manufacturing } \\
\text { Encourage manufacturing SMEs to adopt green } \\
\text { practices, processes, methods and technology } \\
\text { Create awareness among manufacturing SMEs on } \\
\text { green practices }\end{array}$ \\
\hline Research and development initiatives & $\begin{array}{l}\text { - Encourage more research and development on green } \\
\text { systems and practices }\end{array}$ \\
\hline Other supports & $\begin{array}{l}\text { Provision of biogas plants/ solar power systems and } \\
\text { other relevant technologies at low cost or with } \\
\text { subsidies }\end{array}$ \\
\hline
\end{tabular}

\section{Conclusion and Practical Implications}

Successful implementation and sustaining of green practices in manufacturing SMEs strongly need the own will and drive of owners and employees for greening efforts. However, there exist certain macro level initiatives to be taken by the regulatory bodies at the apex level as well as local government level. Government intervention will be essential in promoting and ensuring sustainable green practices in manufacturing SMEs, especially in countries like Sri Lanka due to the reason that 'going green' has still not been fully internalized in the actions of local manufacturers or customers. Thus, popularizing green products, green manufacturing and green purchasing in the local community would be beneficial for all stakeholders involved in the greening process. Manufacturing SMEs themselves need to take actions for disseminating the green practices among peer entrepreneurs. 


\section{Theoretical Implications and Directions for Future Research}

The data collection and the analysis in the present study were supported by the analytical framework developed with the use of existing literature. As per the findings, the manufacturing SMEs should pay their special attention on the following when stepping into the green practices: (1) resources handling, (2) energy consumption, (3) waste handling/ recycling, (4) pollution handling, (5) product life cycle management, (6) reservation of resources, and (8) labour force protection/ handling health and safety. Literature suggests that environmental concerns/ environmental behaviour of the SME owners are not only influential in adopting these practices but also needed for facing the challenges they encounter throughout. As also indicated in the present study, the 'environmental behaviour'is imperative for them to encounter the challenges and handle them strategically. At the same time, the environmental support systems and infrastructure are indispensable in this endeavour. Accordingly, we identify the drive of SME owners in overcoming challenges (which comes in the form of environmental behaviours for adopting green practices) and institutional support as moderators in the relationship between green practices and the resulting performance of manufacturing SMEs. Thus, in line with the findings of this study, it is suggestible to set forth the following model for an empirical test in the manufacturing SMEs in the study of green adoption and their outcomes. This conceptualization is depicted in the Figure 3 below. These hypothetical relationships may be tested in a future empirical study.

\begin{tabular}{|l|}
\multicolumn{1}{|c|}{$\begin{array}{c}\text { Green Manufacturing } \\
\text { Practices (GMPs) }\end{array}$} \\
\hline Resources (material) handling \\
Energy consumption \\
Wastes handling/ recycling \\
Pollution handling \\
Product lifecycle management \\
Reservation of resources \\
Labour force protection// \\
Handling health and safety \\
\hline
\end{tabular}

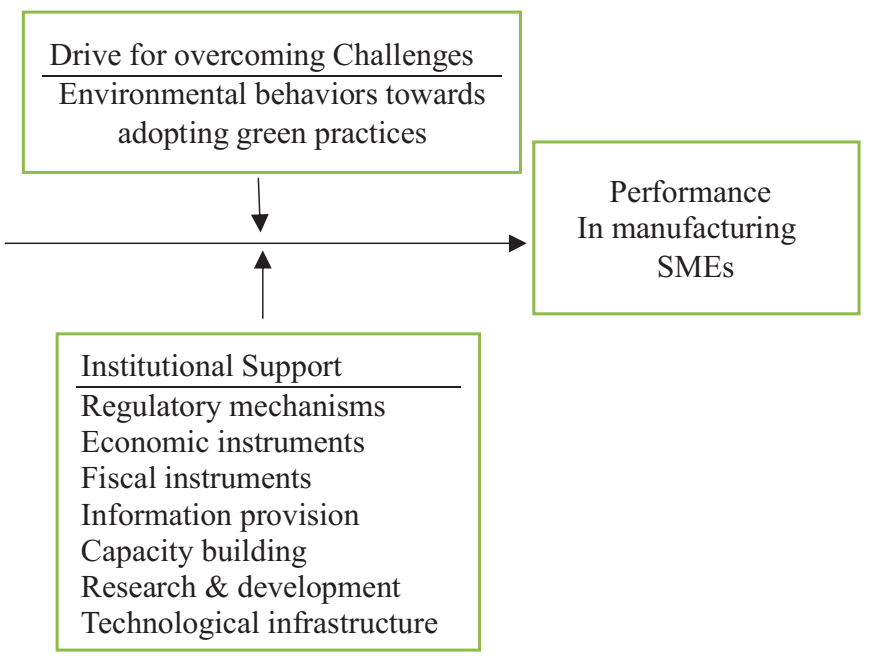

Figure 3: A conceptualization to be tested in a further research 
We encountered the limitation of approaching more case organizations for this study due to certain unavoidable circumstances such as difficulty in spending a longer period of time in a foreign research site. However, we followed the guides of the experts at Kochi for selecting most suitable few cases for the study. Thus, even though the present study captured only few case organisations of manufacturing SMEs in its exploration, it would be more insightful to extend it with the use of more case organizations by using focus groups which put together many relevant stakeholders in one discussion. More importantly, a future research would be to examine the adoption of green practices, challenges encountered and existing or needed institutional support for implementing and sustaining them in the Sri Lankan context. 


\section{References:}

Abbu, N., Bhagavatula, L., Rao-Ghorpade, A., Kolsepatil, N., Kumar, E., Parvathapuram, R., Saini, V., Schraffl, F., Dash, Jo., Dey, P.D., Kumar, S., Raghupathi, U.P., Shah, J., Balasubramania, S., Canan, A., \& Sharma, S. (2015). Urban Green Growth Strategies for India Cities: Green Growth Profiles of Ten Indian Cities, Volume 2, New Delhi, India: ICLEI - Local Governments for Sustainability, South Asia.

Ajin, B. S., Raju, T., \& Prasanth, A.S. (2015). A comprehensive study on implementation of lean manufacturing in coir based SME's in Kerala. International Journal of Engineering Trends and Technology, 30(1), 8-12.

Allwood, J. (2005). Sustainable Manufacturing Seminar Series. Retrieved December 26, 2009, from http://www.ifm.eng.cam.ac.uk/sustainability/ seminar/documents/050216lo.pdf.

Arun, C., \& Noble, P. K. (2017). Factors affecting the implementation of green manufacturing-A case study analysis in an automotive industry. International Research Journal of Engineering and Technology, 4(6), 1945-1948.

Baines, T., Brown, S., Benedettini, O., \& Ball, P. (2012). Examining green production and its role within the competitive strategy of manufacturers. Journal of Industrial Engineering and Management, 5(1), 53-87.

Barreto, L., Anderson, H., Anglin, A., \&Tomovic, C. (2007). Product lifecycle management in support of green manufacturing: Addressing the challenges of Global Climate Change.Proceedings of ICCPR2007, International Conference onComprehensive Product Realization, June 18-20, 2007, Beijing, China.

Berry, M. A., \& Randinelli, D. A. (1998). Proactive corporate environmental management: A new industrial revolution. Academy of Management Executive, 12(2), 38-50.

Bhateja, A.K., Babbar, R., Singh, S., \& Sachdeva, A. (2011). Study of green supply chain management in the Indian manufacturing industries: A literature review cum an analytical approach for the measurement of performance. 
International Journal of Computational Engineering \& Management, 13, 8499.

Burke, S., \& Gaughran, W.F. (2007). Developing a framework for sustainability management in engineering SMEs. Robotics and Computer-Integrated Manufacturing, 23(6), 696-703.

Caniëls, M. C. J., Cleophas, E., \& Semeijn, J. (2016). Implementing green supply chain practices: an empirical investigation in the shipbuilding industry. Maritime Policy \& Management, 43(8), 1005-1020. DOI: 10.1080/03088839.2016. 1182654

Conde, C.D., Abainza, V.C., Reyno, A.B. and Orencia, A.S. (2015), "Enabling SME access to finance for sustainable consumption and production in Asia: An overview of finance trends and barriers in Sri Lanka and the Philippines", Switchasia.

Daily, B.F. \& Huang, S. C. (2001). Achieving sustainability through attention to human resource factors in environmental management. International Journal of Operations \& Production Management, 21(12), 1539-1552.

Dayaratne, S.P, \& Gunawardana, K.D. (2014). Carbon footprint reduction: a critical study of rubber production in small and medium scale enterprises in Sri Lanka. Journal of Cleaner Production, 3, 87-103.

DCSSL, (2017), Final Report for Construction, Trade and Services (Formal Sector):Economic Census 2013/14, Department of Census and Statistics, Colombo, Sri Lanka.

DCSSL, (2015), Non-Agricultural Economic Activities in Sri Lanka: Economic Census 2013/14, Department of Census and Statistics, Colombo, Sri Lanka.

Defi, A. (2011). A system model for green manufacturing. Journal of Cleaner Production, 19, 1553-1559.

del Brío, J.Á. \& B. Junquera, B. (2003). A review of the literature on environmental innovation management in SMEs: implications for public policies. Technovation, 23(12), 939-948. 
Dhillon, M.K. (n.d.). The impact of Indian SME managers/owners on adopting green Supply chain practices. University of Bedfordshire Repository. Retrieved on 15th February 2019 through http://uobrep.openrepository.com/ uobrep/handle/10547/622807

Dhillon, M.K., Bentley, Y. \& Bukoye, T. (2016). Investigating employee attitudes towards adopting green supply chain practices in Indian SMEs - using qualitative methods: Literature review and research methodology. In V. Benson and F. Fillippaios (eds.), Proceedings of the 15th European Conference on Research Methodology for Business and Management Studies (ECRM2016), (pp. 367-374), held on 9-10 June 2016 in the United Kingdom.

Dornfeld, D.A. (2012). Green manufacturing: Fundamentals and applications. New York: Springer.

Dornfeld, D.A., (2014). Moving towards green and sustainable manufacturing. International Journal of Precision Engineering and Manufacturing-Green Technology, 1, 63-66.

Dubey, R., Bag, S., \& Ali, S.S. (2014). Green supply chain practices and its impact on organisational performance: An insight from Indian rubber industry. International Journal of Logistics Systems and Management, 19(1), 20-42.

Dües, C.M., Tan, K.H., \& Lim, M. (2013). Green as the new lean: how to use lean practices as a catalyst to greening your supply chain, Journal of Clean Production, 40, 93-100.

Economic Review 2016. (2019). Government of Kerala. Retrieved on 10th January 2019 through http://spb.kerala.gov.in/EconomicReview2016/ web/chapter 03_03.php

Esty, D.C. \& Winston, A. (2006). Green to gold: How smart companies use environmental strategy to innovate, create value, and build competitive advantage. NJ: John Wiley and Sons.

Ghazilla, R.A.R., Sakundarini, N., Abdul-Rashid, S.H., Ayub, N.S., Olugu, E.U., $\&$ Musa, S.N. (2015). Drivers and barriers analysis for green manufacturing 
practices in Malaysian SMEs: A Preliminary Findings. Procedia CIRP, 26, 658-663. doi: 10.1016/j.procir.2015.02.085

Gibbs, D. (2009). Sustainability Entrepreneurs, Ecopreneurs and theDevelopment of a Sustainable Economy. Greener Management International, 55, 63-78.

Gopichandran, R., Shah, V.N., Patel, N.J. \& Harinarayana, T. (2013). SMEs can overcome challenges and improve sustainability through preventive management strategies: Some empirical evidences from a cluster of chemical industries in Western India. International Journal of Globalisation and Small Business, 5(3), 209-223.

Govindan, K., Kaliyan, M., Kannan, D., \& Haq, A.N. (2014). Barriers analysis for green supply chain management implementation in Indian industries using analytic hierarchy process. International Journal of Production Economics, $147,555-568$.

Grieves, M. (2006). Product lifecycle management: Driving the next generation of lean thinking.

New York: McGraw Hill.

Green Business Bureau (2020). How To Be A Successful Ecopreneur (2020). https://greenbusinessbureau.com/blog/how-to-be-a-successful-ecopreneur/

Hartinia, S., \& Ciptomulyonob, U. (2015). The relationship between lean and sustainable manufacturing on performance: literature review. Procedia Manufacturing, 4, 38-45.

Jaiswal, P. \& Kumar, A. (2018). Prioritisation of barriers in implementation of green manufacturing in Indian SMEs through integrated grey-DEMATEL approach. International Journal of Manufacturing Technology and Management, 32(3), 215-236.

Joseph, K. (12th May 2010). Why hand-weaving is a technology for the 21st century. Ecologist: The Journal for the Post-industrial Era, Retrieved on 11th January 2019 through https://theecologist.org/2010/may/12/why-handweaving-technology-21st-century 
Kaur, G.P., Gupta, P., \& Syal, M. (2016). Adoption of Green Practices in Industrial Buildings: An Action Research on Capacity Building of Stakeholders Towards Green Factories. Sustainable Land Use and Urban Planning, 3(2), $1-12$.

Kirkwood, J. \& Walton, S. (2010). What motivates ecopreneurs to start businessesfi International Journal of Entrepreneurial Behavior \& Research, 16(3), 204-228. https://doi.org/10.1108/13552551011042799

Kumar, M., Kumar, V. \& Ram, P. (2015). Factors affecting Green SCM Implementation in MSMEs. International Journal of Innovative Science, Engineering \& Technology, 2(12), 631-645.

Lee, K. (2009). Why and how to adopt green management into business organizationsfi: The case study of Korean SMEs in manufacturing industry. Management Decision, 47(7), 1101-1121. doi.org/ 10.1108/00251740910978322

Lin, P.C. \& Huang, Y.H. (2012). The influence factors on choice behavior regarding green products based on the theory of consumption values. Journal of Cleaner Production,22(1), 11-18.

Liu, J.Y., Low, S.P., \& He, X. (2012). Green practices in the Chinese building industry: drivers and impediments. Journal of Technology Management in China, 7, 50-63.

Mafini, C. \& Loury-Okoumba, W.V. (2018). Extending green supply chain management activities to manufacturing small and medium enterprises in a developing economy. South African Journal of Economic and Management Sciences, 21(1), a1996.https://doi.org/ 10.4102/sajems.v21i1.1996

Manufacturing Matters (2011). CII organizes first Green Manufacturing Summit. Author. Retrieved on 18th December 2018 through file:///E:/Green\% 20Concept/Green\%20Concept_Manufacturing\%20Matters.pdf

Miller, G., Pawloski, J., \& Standridge, C. (2010). A case study of lean, sustainable manufacturing. Journal of Industrial Engineering and Management, 3(1), 11-32. doi:10.3926/jiem.2010.v3n1.p11-32 